\title{
PENGUASAAN KONSEP GEOMETRI PADA SISWA SMP KOTA PONTIANAK TAHUN 2020
}

\author{
Rustam \\ Staf Pengajar Program Studi Matematika FKIP Untan \\ Email: rustam@fkip.untan.ac.id
}

\begin{abstract}
This research was motivated by several reasons: (1) there was a misconception of some elementary school geometry materials that were considered essential; (2) the form of evaluation given was dominantly objective/multiple choice; (3) teachers' teaching methods tend not to be contextual; and (4) students' way of thinking simply to take the practical one. Through this research, it is expected to obtain information about: geometrical reasoning in elementary schools according to Bruner's theory, problem solving and mathematical representations. The research was conducted in a descriptive analytic form, with the following steps: (1) giving questions for the geometry reasoning test for SMP; (2) analyzing answers according to the criteria of reasoning; and (3) mapping students' answers to the results of the analysis according to the profile criteria. The data obtained were analyzed, and the results were described to illustrate the condition of the geometric reasoning abilities of elementary school students. The results obtained in this study were: (1) The Mastery of the concept of geometry in each junior high school/equivalent. The target with the acquisition of an average score from all schools was 55, which was quite low because there were some students who did not master the concept of geometry and there were other mathematical concepts related to solving test questions; (2) There was no significant difference in the mastery of geometry concepts for male or female students for each SMP/equivalent target, except for one school, namely SMP Negeri 17, which was because males are superior to females in three questions with a difference in the percentage of numbers of significantly correct; (3) The mastery of geometry concepts in each junior high school. The target of studying each geometry material was considered good, except for question number 1 with the subject of the Pythagorean Theorem, because students were dominant in not being able to use the relationship between concepts, especially the operation of the compounding form and the roots.
\end{abstract}

\section{Keywords: Geometry Reasoning, Junior High School}

\begin{abstract}
Abstrak
Penelitian ini dilatarbelakangi beberapa hal, yaitu: (1) terjadi miskonsepsi terhadap beberapa materi geometri sekolah dasar yang dianggap esensial; (2) bentuk evaluasi yang diberikan dominan objektif/pilihan ganda; (3) cara mengajar guru cenderung belum kontekstual; dan (4) cara berpikir siswa sekedar mengambil yang praktis. Melalui penelitian ini diharapkan dapat memperoleh informasi tentang: penalaran geometri di sekolah dasar sesuai teori Bruner, pemecahan masalah dan representasi matematis. Penelitian dilakukan dalam bentuk deskriptif analitik, yaitu dengan tahapan: (1) memberikan soal tes penalaran geometri SMP; (2) menganalisis jawaban sesuai kriteria penalaran; dan (3) memetakan jawaban siswa hasil analisis sesuai kriteria profil. Data yang diperoleh tersebut dianalisis, dan hasilnya dideskripsikan yang menggambarkan tentang kondisi kemampuan penalaran geometris siswa sekolah dasar. Hasil yang diperoleh dalam penelitian ini sebagai berikut: (1) Penguasaan konsep geometri pada siswa masing-masing SMP/Sederajat Sasaran dengan perolehan nilai rata-rata dari seluruh sekolah adalah 55, tergolong cukup rendah yang dikarenakan terdapat beberapa siswa yang kurang menguasai konsep geometri dan ada konsep matematika lainnya yang berhubungan dengan penyelesaian soal tes; (2) Tidak ada perbedaan yang signifikan terhadap penguasaan konsep geometri laki-laki ataupun perempuan masing-masing SMP/Sederajat Sasaran, kecuali pada salah satu sekolah yaitu SMP Negeri 17 yang dikarenakan laki-laki lebih unggul daripada
\end{abstract}


perempuan di tiga soal dengan perbedaan persentase jumlah benar yang signifikan; (3) Penguasaan konsep geometri masing-masing SMP Sasaran dikaji masing-masing materi geometri dinilai baik, kecuali pada soal nomor 1 dengan materi Teorema Phytagoras, karena dominan para siswa kurang dapat menggunakan hubungan antar konsep, terutama operasi bentuk perpangkaatan dan akar.

\section{Kata Kunci: Penalaran Geometri, Sekolah Menengah Pertama}

\section{PENDAHULUAN}

Matematika merupakan salah satu mata pelajaran yang sangat penting untuk dipelajari oleh setiap siswa di sekolah. Dalam kurikulum dijelaskan bahwa tujuan diberikannya matematika antara lain agar siswa mampu menghadapi perubahan keadaan di bumi yang selalu berkembang, melalui latihan bertindak atas dasar pemikiran secara logis, rasional, kritis, cermat, jujur, dan efektif.Berdasarkan Permendikbud Nomor 22 Tahun 2016 mengenai tujuan pembelajaran matematika Selain itu, NCTM (National Council of Teachers of Mathematics) merekomendasikan 4 (empat) prinsip pembelajaran matematika, yaitu (a) matematika untuk memecahan masalah, (b) matematika untuk menalar, (c) matematika untuk komunikasi, dan (d) matematika untuk menghubungkan. Jadi, tujuan yang dimaksud dari pembelajaran matematika di SMP ini yaitu siswa dapat memecahkan masalah yang berkaitan dengan matematika dengan berfikir kritis, logis dan cermat untuk dapat menyelesaiakan permasalahan matematika serta untuk menitih pendidikan ke jenjang selanjutnya.

Memperhatikan tujuan pembelajaran matematika tersebut, selayaknya perlu diperhatikan beberapa unsur matematis yang mendasari dan memperkuat konsep matematika. Salah satu diantaranya adalah geometri. Bila dikaji lebih lanjut, ternyata penguasaan materi geometri cukup berperan untuk membelajarkan matematika yang bermakna. Namun kenyataan yang dilami saat ini, penguasaan materi geometri saat ini belum seperti yang diharapkan.

Hasil survei tentang 2 soal geometri materi gradien pada 62 siswa SMP yang duduk di kelas 8 diperoleh beberapa informasi sebagai berikut. Pertama, sekitar 58\% siswa masih belum tepat dalam penggunaan rumus gradien dan penerapannya. Sebagian besar mereka kurang tepat dalam penggunaan rumus gradien antara satu titik dan dua titik. Kedua, ketika diminta untuk mempresentasikan hasil yang diperoleh dalam beberapa bentuk representasi geometris yang lain, hanya 35\% siswa yang benar. Sebagian beser beralasan, mereka lebih nyaman dan aman dengan representasi yang ada. Ketiga, dalam hal membaca simbol mereka kurang begitu terbiasa, karena mereka beranggapan bahwa hasil proses yang ada lebih diperhatikan oleh guru, dibanding dengan kesalahan dalam penulisan simbol.

Demikian juga halnya dalam mengomunikasikan konsep geometri yang dipahami. Tidak jarang terjadi miskonsepsi pada siswa, bahkan pada guru. dan juga dengan soalsoal geometri yang dikaitkan dengan pemecahan masalah sehari-hari. Hasil tanya jawab dengan siswa dan guru bahwa siswa kurang dikondisikan untuk menyelesaikan soal-soal yang dikaitkan dengan kehidupan sehari-hari.Dari paparan di atas tentang penguasaan geometri, ternyata belum optimal dikuasai siswa. Memperhatikan perlunya kajian penalaran yang mendalam berdasarkan fakta-fakta yang diperoleh, pertimbangan beberapa ahli terkait dengan penguasaan materi geometri; maka peneliti tertarik untuk mengkaji lebih jauh. Kajian yang dimaksud dikondisikan dalam suatu penelitian dengan judul: "Penguasaan Konsep Geometri pada Siswa SMP Kota Pontianak Tahun 2020". Dimana tujuan penelitian ini sebagai berikut: untuk mendeskripsikan tentang penguasaan konsep geometri pada siswa masing-masing SMP Sasaran, untuk mendeskripsikan tentang penguasaan konsep geometri masing-masing SMP Sasaran dikaji dari jenis kelamin dan ntuk mendeskripsikan tentang penguasaan konsep geometri masing-masing SMP Sasaran dikaji masing-masing materi geometri.

Pembelajaran Geometri. Unsur-unsur geometri dikenal siswa sejak awal di bangku sekolah. Mengenali geometri sejak awal ternyata tidak menjamin siswa memahami unsur geometri tersejak awal juga. Bagi siswa yang masih duduk di kelas rendah, pemahaman konsep-konsep geometri cenderung dilakukan dengan cara hapalan, serta tergantung variasi atau monoton instruksi dari pengajar. Pembelajaran geometri pada sekolah dasar terutama siswa kelas bahwa cenderung mengikuti teori Bruner. Dalam realisasinya, beberapa konsep geometri maupun matematika yang diajarkan pada siswa kelas rendah, dimulai dari hal yang nyata dan sesuai konteks siswa.

Tingkat perkembangan dan kemajuan yang telah dicapai berbagai ilmu pengetahuan dan teknologi dewasa ini tidak lepas dari peranan matematika. Matematika bukan hanya untuk 
keperluan kalkulasi, tetapi lebih dari itu matematika telah banyak digunakan untuk pengembangan berbagai ilmu pengetahuan lain, seperti yang dikemukakan oleh Soedjadi bahwa matematika sebagai salah satu ilmu dasar, baik aspek terapannya maupun aspek penalarannya mempunyai peranan yang penting dalam upaya penguasaan ilmu dan teknologi (Soedjadi, 2004: 28).

Konsep. Piaget berpendapat bahwa pada dasarnya setiap individu sejak kecil sudah memiliki kemampuan untuk mengkonstruksi pengetahuannya sendiri. Mengkonstruksi pengetahuan menurut Piaget dilakukan melalui proses asimilasi dan akomodasi terhadap skema yang sudah ada. Skema adalah struktur kognitif yang terbentuk melalui proses pengalaman (Sanjaya, 2006: 123-124).

Dalam penguasaan konsep dan struktur matematika, mahasiswa harus membentuk konsep atau struktur melalui pengalaman sebelumnya. Konsep atau struktur baru haruslah bermakna bagi siswa artinya konsep tersebut cocok dengan kemampuan yang dimiliki mahasiswa serta relevan dengan kemampuan kognitif (Hudojo, 2005:72).

Menurut Arifin Jos (2001), konsep adalah gambaran mental dari obyek, proses atau apapun yang ada di luar bahasa yang digunakan oleh akal budi untuk memahami hal-hal lain. Sedangkan menurut Herman Hudojo (2003:124), konsep adalah suatu ide abstrak yang memungkinkan kita mengklasifikasikan objek-objek dan peristiwaperistiwa itu termasuk atau tidak ke dalam ide abstrak tersebut.

Berdasarkan uraian tersebut, dapat disimpulkan bahwa konsep merupakan suatu pengertian yang dapat digunakan atau memungkinkan seseorang untuk mengelompokkan atau menggolongkan suatu obyek atau peristiwa termasuk atau tidak termasuk dalam pengertian tersebut.

Penguasaan Konsep Matematika. Wirasto (1987) memberikan ciri-ciri siswa yang sudah menguasai konsep. Penyajian konsep atau ide matematika yang baru harus didasarkan pada pengalaman yang terdahulu karena siswa akan ingat konsep-konsep yang baru lebih baik bila konsep tersebut tidak bertentangan dengan konsep yang telah dikenal sebelumnya (Herman Hudojo, 2003:86).

Beberapa langkah yang dapat dilakukan seorang guru dalam mengajarkan suatu konsep dalam matematika (Thomas J.Cooney, dkk: 91-105) diantaranya: a. Mendefinisikan suatu objek; b. Memberikan satu atau lebih contoh-contoh dari suatu obyek; c. Memberikan sebuah contoh objek dengan menyebutkan alasan mengapa obyek tersebut merupakan suatu contoh; $d$. Membandingkan dan menegaskan objek-objek yang ditunjukkan oleh suatu konsep; e. Menyatakan syarat perlu dan syarat cukup bahwa suatu objek dapat dikategorikan kedalam jenis obyek lain; $f$ Memberikan satu atau lebih suatu objek yang bukan contoh dari objek lain; g. Memberikan alasan mengapa suatu objek yang bukan contoh dari objek lain; h. Memberikan karakteristik yang bukan merupakan syarat perlu dan syarat cukup objek-objek yang ditunjukkan oleh suatu konsep

Dari dua pendapat ahli di atas, peneliti dapat menyimpulkan dengan mengkombinasikan dua pendapat tersebut bahwa siswa dikatakan menguasai suatu konsep dalam pembelajaran matematika bila memenuhi tujuh kriteria penguasaan. a. Mengetahui ciri-ciri atau definisi suatu konsep; b. Mengenal beberapa contoh dan bukan contoh dari konsep tersebut; c. Memberikan sebuah contoh objek dengan menyebutkan alasan mengapa obyek tersebut merupakan suatu contoh; d. Dapat menggunakan hubungan antar konsep; e. Dapat mengenal kembali konsep itu dalam berbagai situasi; f. Dapat menggunakan konsep untuk menyelesaikan masalah matematika; g. Khusus dalam geometri, dapat mengenal wujud, dapat meragakan, dan mengenal persamaannya

Penguasaan Konsep Geometri. Dengan demikian, penguasaan konsep matematika merupakan produk dari suatu kegiatan belajar seseorang untuk mengerti dan memahami suatu obyek-obyek atau benda-benda melalui pengamatan dan pengalaman seseorang dalam menyelesaikan masalah matematika, sehingga penguasaan konsep ini menjadi konsep yang tidak mudah hilang.

Agar siswa dapat mengingat suatu konsep matematika untuk jangka waktu yang lama maka siswa harus memperoleh konsep tersebut dengan cara menggunakan kehidupan sehari-hari yang diformulasikan dengan pembelajaran matematika, tentunya dengan bantuan guru sebagai fasilitator. Sedangkan siswa dapat menguasai konsep geometri jika memenuhi kriteria penguasaan konsep seperti dalam tabel berikut.

Tabel 1. Kriteria Penguasaan Konsep Geometri dan Kemampuan Berpikir

\begin{tabular}{lll}
\hline No & Kriteria Penguasaan Konsep Geometri & Kemampuan Berpikir \\
\hline 1 & Mengetahui ciri-ciri atau definisi suatu konsep geometri & Mengingat
\end{tabular}


2 Membedakan yang tergolong contoh dan bukan contoh konsep Menganalisis geometri tersebut, yang disertai alasan relevan dan logis.

\begin{tabular}{lll}
\hline 3 & Dapat menggunakan hubungan antar konsep & Mengaplikasikan \\
\hline 4 & Dapat mengenal kembali konsep itu dalam berbagai situasi & Mengevaluasi \\
\hline 5 & $\begin{array}{l}\text { Dapat menggunakan konsep untuk menyelesaikan masalah } \\
\text { matematika }\end{array}$ & Mencipta \\
\hline 6 & $\begin{array}{l}\text { Mampu mengubah antar bentuk simbolik/ persamaan, } \\
\text { verbalis, dan visual/ konkreat. }\end{array}$ & Menganalisis \\
\hline
\end{tabular}

Dalam kajian lebih lanjut, penguasan konsep geometri tersebut dapat menggambarkan kemampuan berpikir siswa pada level tertentu. Masuk kriteri LOWS (Lower Order Thinking Skills) atau HOTS (Higher Order Thinking Skills). Dengan demikian, setidaknya menggambarkan kondisi umum siswa pada materi geometri dari aspek kemampuan berpikir.

\section{METODE PENELITIAN}

Metode pada penelitian ini adalah Metode deskriptif dianggap peneliti dapat menjelaskan penguasaan konsep geometri siswa SMP. Subjek dalam penelitian ini terdiri 8 SMP di Kota Pontianak, yaitu empat SMP Negeri dan empat SMP Swasta. Selanjutnya seluruh subjek tersebut diberikan tes tertulis tentang konsep geometri. Dari seluruh subjek tersebut yang diwawancarai masing-masing 2 orang sebagai perwakilan sekolah. Penetapan 2 orang tersebut didasarkan pada penunjukan masing-masing guru dan objek dalam penelitian ini adalah penguasaan konsep geometri siswa SMP.

Teknik tes yang dimaksud dalam penelitian ini adalah tes tertulis. Tes tertulis yang digunakan dalam penelitian ini adalah tes yang menggali konsep geometris. Teknik komunikasi langsung merupakan cara mengumpulkan data melalui pertanyaan yang disampaikan secara lisan yang dilakukan dengan cara memberi seperangkat pertanyaan atau pernyataan lisan berupa dialog.

Adapun alat pengumpulan data yang digunakan dalam penelitian ini yaitu tes dan wawancara sedangkan dalam penyusun tes digunakan prosedur penyusunan tes, meliputi penyusunan kisi-kisi soal, penulisan butir soal, uji validitas butir soal, dan reliabilitas.

Teknik analisis data yang digunakan dalam penelitian ini menggunakan teknik analisis data kualitatif. Bogan (dalam Sugiyono, 2015: 334) menyatakan bahwa "Data analysis is the process of sistematically searching and arranging the interview transcripts, fieldnotes, and other materials that you accumulate to increase your own understanding of them and to enable you to present what you has discovered to others" yang artinya analisis data adalah proses mencari dan menyusun secara sistematis data yang diperoleh hasil wawancara, catatan lapangan, dan bahanbahan lain, sehingga dapat mudah dipahami, dan temuannya dapat diinformasikan kepada orang lain.

\section{HASIL DAN PEMBAHASAN}

Penelitian ini bertujuan penguasaan konsep geometri pada siswa masing-masing SMP/Sederajat Sasaran secara umum, terhadap tinjauan berdasarkan jenis kelamin, dan terhadap tinjauan berdasarkan masing-masing materi geometri. Pelaksanaan penelitian dilakukan via dalam jaringan (daring) berbentuk pertanyaan dan sepuluh soal test.

Penguasaan Konsep Geometri Pada Siswa MTs. Al-Irsyad. Siswa dari MTs. Al-Irsyad yang menjadi Responden sebanyak 30 orang, terdiri dari 11 laki-laki dan 19 perempuan. Ketika para responden menjawab sepuluh soal test, rata-rata nilai mereka adalah 53 dengan rata-rata nilai lakilaki lebih rendah dari rata-rata nilai perempuan yaitu sekitar 45 berbanding 58. Selain itu, nilai tertingginya adalah 100 dan terendah adalah 10 .

Tabel 2. Data Jumlah Jawaban Benar Siswa MTs. Al-Irsyad

$$
\text { MTs. Al-Irsyad }
$$

\begin{tabular}{cccc}
\hline \multicolumn{1}{c}{ Total Responden : 30 Orang, Terdiri dari 11 Laki-laki dan 19 Perempuan } \\
No. & $\begin{array}{c}\text { Jumlah Jawaban } \\
\text { Benar Laki-Laki }\end{array}$ & $\begin{array}{c}\text { Jumlah Jawaban } \\
\text { Benar Perempuan }\end{array}$ & $\begin{array}{c}\text { Persentase Jawaban Benar } \\
\text { Responden Dengan Total } \\
\text { Responden }\end{array}$ \\
\hline 1 & 4 & 6 & $33 \%$ \\
\hline 2 & 7 & 11 & $60 \%$ \\
\hline 3 & 6 & 12 & $60 \%$ \\
\hline
\end{tabular}




\begin{tabular}{cccc}
\hline 4 & 4 & 11 & $50 \%$ \\
\hline 5 & 6 & 11 & $57 \%$ \\
\hline 6 & 4 & 10 & $47 \%$ \\
\hline 7 & 3 & 12 & $50 \%$ \\
\hline 8 & 8 & 12 & $67 \%$ \\
\hline 9 & 4 & 13 & $57 \%$ \\
\hline 10 & 5 & 12 & $57 \%$ \\
\hline
\end{tabular}

Berdasarkan tabel tersebut, Soal dengan jumlah jawaban benar lebih dari atau sama dengan $50 \%$ dari total soal adalah nomor $2,3,4,5,7,8,9$ dan 10. Jika ditinjau lebih lanjut dari jenis kelamin, tidak ada perbedaan nilai yang siknifikan antara laki-laki dan perempuan kecuali soal nomor 7 yang selisih persentasenya sekitar $36 \%$.

Penguasaan Konsep Geometri Pada Siswa MTs. Al-Ihsan. Siswa dari MTs. Al-Irsyad yang menjadi Responden sebanyak 32 orang, terdiri dari 15 laki-laki dan 17 perempuan. Ketika para responden menjawab sepuluh soal test, rata-rata nilai mereka adalah 54 dengan rata-rata nilai lakilaki lebih rendah dari rata-rata nilai perempuan yaitu sekitar 50 berbanding 58. Secara umum berdasarkan jumlah jawaban benar, dapat dilihat pada tabel di bawah ini:

Tabel 3. Data Jumlah Jawaban Benar Siswa MTs. Al-Ihsan

MTs. Al-Ihsan

Total Responden : 32 Orang, terdiri dari 15 Laki-laki dan 17 Perempuan

$\begin{array}{lccc}\text { Soal No. } & \begin{array}{l}\text { Jumlah Jawaban } \\ \text { Benar Laki-Laki }\end{array} & \begin{array}{c}\text { Jumlah Jawaban } \\ \text { Benar Perempuan }\end{array} & \begin{array}{c}\text { Persentase Jawaban Benar } \\ \text { Responden Dengan Total }\end{array}\end{array}$

\begin{tabular}{cccc} 
& & & Responden \\
\hline 1 & 7 & 6 & $41 \%$ \\
\hline 2 & 9 & 14 & $72 \%$ \\
\hline 3 & 5 & 8 & $41 \%$ \\
\hline 4 & 7 & 9 & $50 \%$ \\
\hline 5 & 8 & 13 & $66 \%$ \\
\hline 6 & 1 & 3 & $13 \%$ \\
\hline 7 & 7 & 7 & $44 \%$ \\
\hline 8 & 11 & 14 & $78 \%$ \\
\hline 9 & 10 & 13 & $72 \%$ \\
\hline 10 & 10 & 12 & $69 \%$ \\
\hline
\end{tabular}

Berdasarkan tabel tersebut, Soal dengan jumlah jawaban benar lebih dari atau sama dengan $50 \%$ dari total soal adalah nomor 2, 4, 5, 8, 9 dan 10. Jika ditinjau lebih lanjut dari jenis kelamin, tidak ada perbedaan nilai yang siknifikan antara nilai laki-laki dan perempuan.

Penguasaan Konsep Geometri Pada Siswa SMP Negeri 17. Siswa dari SMP Negeri 17 yang menjadi Responden sebanyak 23 orang, terdiri dari 6 laki-laki dan 17 perempuan. Ketika para responden menjawab sepuluh soal test, rata-rata nilai mereka adalah 45 dengan rata-rata nilai lakilaki lebih tinggi dari rata-rata nilai perempuan yaitu sekitar 58 berbanding 31 Selain itu, nilai tertingginya adalah 80 dan terendah adalah 0 . Secara umum berdasarkan jumlah jawaban benar, dapat dilihat pada tabel di bawah ini:

Tabel 4. Data Jumlah Jawaban Benar Siswa SMP Negeri 17

SMP Negeri 17

Total Responden : 23 Orang, terdiri dari 6 Laki-laki dan 17 Perempuan

$\begin{array}{llc}\text { Soal No. Jumlah Jawaban } & \text { Jumlah Jawaban } \\ \text { Benar Laki-Laki } & \text { Benar Perempuan }\end{array}$

\begin{tabular}{cccc}
\hline Soal No. & $\begin{array}{c}\text { Jumlah Jawaban } \\
\text { Benar Laki-Laki }\end{array}$ & $\begin{array}{c}\text { Jumlah Jawaban } \\
\text { Benar Perempuan }\end{array}$ & $\begin{array}{c}\text { Persentase Jawaban Benar } \\
\text { Responden Dengan Total } \\
\text { Responden }\end{array}$ \\
\hline 1 & 2 & 1 & $13 \%$ \\
\hline 2 & 5 & 8 & $57 \%$ \\
\hline 3 & 3 & 6 & $39 \%$ \\
\hline 4 & 3 & 9 & $52 \%$ \\
\hline 5 & 4 & 5 & $39 \%$ \\
\hline 6 & 2 & 2 & $17 \%$ \\
\hline
\end{tabular}




\begin{tabular}{cccc}
\hline 7 & 3 & 5 & $35 \%$ \\
\hline 8 & 5 & 9 & $61 \%$ \\
\hline 9 & 5 & 6 & $48 \%$ \\
\hline 10 & 4 & 4 & $35 \%$
\end{tabular}

Berdasarkan tabel tersebut, Soal dengan jumlah jawaban benar lebih dari atau sama dengan $50 \%$ dari total soal adalah nomor 2,4 , dan 8 . Jika ditinjau lebih lanjut dari jenis kelamin, tidak ada perbedaan nilai yang siknifikan antara nilai lakilaki dan perempuan, kecuali nomor 2 sekitar $36 \%$ , nomor 9 sekitar $48 \%$, dan nomor 10 sekitar $43 \%$.
Penguasaan Konsep Geometri Pada Siswa SMP Negeri 18. Siswa dari SMP Negeri 18 yang menjadi Responden sebanyak 69 orang, terdiri dari 23 laki-laki dan 46 perempuan. Secara umum berdasarkan jumlah jawaban benar, dapat dilihat pada tabel di bawah ini:

Tabel 5. Data Jumlah Jawaban Benar Siswa SMP Negeri 18

SMP Negeri 18

Total Responden : 69 Orang, terdiri dari 23 Laki-laki dan 46 Perempuan

$\begin{array}{cccc}\text { Soal No. } & \begin{array}{c}\text { Jumlah Jawaban } \\ \text { Benar Laki-Laki }\end{array} & \begin{array}{c}\text { Jumlah Jawaban } \\ \text { Benar Perempuan }\end{array} & \begin{array}{c}\text { Persentase Jawaban Benar } \\ \text { Responden Dengan Total }\end{array}\end{array}$

\begin{tabular}{cccc}
\hline 1 & 3 & 13 & Responden \\
\hline 2 & 21 & 42 & $23 \%$ \\
\hline 3 & 17 & 40 & $81 \%$ \\
\hline 4 & 13 & 17 & $43 \%$ \\
\hline 5 & 17 & 29 & $67 \%$ \\
\hline 6 & 9 & 25 & $49 \%$ \\
\hline 7 & 13 & 28 & $59 \%$ \\
\hline 8 & 23 & 42 & $94 \%$ \\
\hline 9 & 21 & 36 & $83 \%$ \\
\hline 10 & 22 & 38 & $87 \%$ \\
\hline
\end{tabular}

Berdasarkan tabel tersebut, Soal dengan jumlah jawaban benar lebih dari atau sama dengan $50 \%$ dari total soal adalah nomor $2,3,5,7,8,9$, dan 10. Jika ditinjau lebih lanjut dari jenis kelamin, tidak ada perbedaan nilai yang siknifikan antara nilai laki-laki dan perempuan.
Penguasaan Konsep Geometri Pada Siswa SMP Negeri 19. Siswa dari SMP Negeri 19 yang menjadi Responden sebanyak 11 orang, terdiri dari 4 laki-laki dan 7 perempuan. Secara umum berdasarkan jumlah jawaban benar, dapat dilihat pada tabel di bawah ini:

Tabel 6. Data Jumlah Jawaban Benar Siswa SMP Negeri 19

$$
\text { SMP Negeri } 19
$$

Total Responden : 11 Orang, terdiri dari 4 Laki-laki dan 7 Perempuan

\begin{tabular}{cccc}
\hline $\begin{array}{c}\text { Soal } \\
\text { No. }\end{array}$ & $\begin{array}{c}\text { Jumlah Jawaban } \\
\text { Benar Laki-Laki }\end{array}$ & $\begin{array}{c}\text { Jumlah Jawaban } \\
\text { Benar Perempuan }\end{array}$ & $\begin{array}{c}\text { Persentase Jawaban Benar Responden } \\
\text { Dengan Total Responden }\end{array}$ \\
\hline 1 & 2 & 0 & $18 \%$ \\
\hline 2 & 4 & 6 & $91 \%$ \\
\hline 3 & 2 & 4 & $55 \%$ \\
\hline 4 & 3 & 3 & $55 \%$ \\
\hline 5 & 4 & 6 & $91 \%$ \\
\hline 6 & 0 & 0 & $0 \%$ \\
\hline 7 & 1 & 4 & $45 \%$ \\
\hline 8 & 4 & 5 & $82 \%$ \\
\hline 9 & 2 & 3 & $45 \%$ \\
\hline 10 & 2 & 5 & $64 \%$ \\
\hline
\end{tabular}

Berdasarkan tabel tersebut, Soal dengan jumlah jawaban benar lebih dari atau sama dengan $50 \%$ dari total soal adalah nomor $2,3,4,5,8$, dan 10. Jika ditinjau lebih lanjut dari jenis kelamin, tidak ada perbedaan nilai yang siknifikan antara nilai laki-laki dan perempuan, kecuali pada nomor 1 sekitar 50\%, nomor 4 sekitar $32 \%$, nomor 7 sekitar 32\%, dan nomor 8 sekitar $29 \%$. 
Penguasaan Konsep Geometri Pada Siswa SMP Negeri 20. Siswa dari SMP Negeri 20 yang menjadi Responden sebanyak 41 orang, terdiri dari 18 laki-laki dan 23 perempuan. Ketika para responden menjawab sepuluh soal test, rata-rata nilai mereka adalah sekitar 60 dengan rata-rata nilai laki-laki lebih rendah dari rata-rata nilai perempuan yaitu sekitar 56 berbanding 64 Selain itu, nilai tertingginya adalah 90 dan terendah adalah 10. Secara umum berdasarkan jumlah jawaban benar, dapat dilihat pada tabel di bawah ini:

Tabel 7. Data Jumlah Jawaban Benar Siswa SMP Negeri 20

SMP Negeri 20

Total Responden : 41 Orang, terdiri dari 18 Laki-laki dan 23 Perempuan

\begin{tabular}{cccc}
\hline $\begin{array}{c}\text { Soal } \\
\text { No. }\end{array}$ & $\begin{array}{c}\text { Jumlah Jawaban } \\
\text { Benar Laki-Laki }\end{array}$ & $\begin{array}{c}\text { Jumlah Jawaban } \\
\text { Benar Perempuan }\end{array}$ & $\begin{array}{c}\text { Persentase Jawaban Benar Responden } \\
\text { Dengan Total Responden }\end{array}$ \\
\hline 1 & 5 & 11 & $39 \%$ \\
\hline 2 & 13 & 17 & $73 \%$ \\
\hline 3 & 12 & 17 & $71 \%$ \\
\hline 4 & 8 & 15 & $56 \%$ \\
\hline 5 & 15 & 15 & $73 \%$ \\
\hline 6 & 2 & 7 & $22 \%$ \\
\hline 7 & 9 & 13 & $54 \%$ \\
\hline 8 & 14 & 16 & $73 \%$ \\
\hline 9 & 11 & 20 & $76 \%$ \\
\hline 10 & 12 & 17 & $71 \%$ \\
\hline
\end{tabular}

Berdasarkan tabel tersebut, Soal dengan jumlah jawaban benar lebih dari atau sama dengan $50 \%$ dari total soal adalah nomor 2, 3, 4, 5, 7, 8, 9, dan 10. Selain itu, soal dengan jawaban benar terbanyak adalah nomor 9 dan soal dengan jawaban benar tersedikit adalah nomor 6. Jika ditinjau lebih lanjut dari jenis kelamin, tidak ada perbedaan nilai yang siknifikan antara nilai laki- laki dan perempuan, kecuali pada nomor 9 sekitar $26 \%$.

Penguasaan Konsep Geometri Pada Siswa SMP Negeri 22. Siswa dari SMP Negeri 22 yang menjadi Responden sebanyak 37 orang, terdiri dari 14 laki-laki dan 23 perempuan. Secara umum berdasarkan jumlah jawaban benar, dapat dilihat pada tabel di bawah ini:

Tabel 8. Data Jumlah Jawaban Benar Siswa SMP Negeri 20

SMP Negeri 22

\section{Total Responden : 37 Orang, terdiri dari 14 Laki-laki dan 23 Perempuan}

Soal No. Jumlah Jawaban Benar Laki-Laki

\section{Jumlah Jawaban Benar Perempuan}

\section{Persentase Jawaban Benar \\ Responden Dengan Total} Responden

\begin{tabular}{lccc}
\hline $\mathbf{1}$ & 3 & 6 & $24 \%$ \\
\hline $\mathbf{2}$ & 8 & 17 & $68 \%$ \\
\hline $\mathbf{3}$ & 5 & 16 & $57 \%$ \\
\hline $\mathbf{4}$ & 5 & 6 & $30 \%$ \\
\hline $\mathbf{5}$ & 6 & 14 & $54 \%$ \\
\hline $\mathbf{6}$ & 1 & 4 & $14 \%$ \\
\hline $\mathbf{7}$ & 7 & 13 & $54 \%$ \\
\hline
\end{tabular}




\begin{tabular}{cccc}
\hline $\mathbf{8}$ & 9 & 19 & $76 \%$ \\
\hline $\mathbf{9}$ & 7 & 17 & $65 \%$ \\
\hline $\mathbf{1 0}$ & 7 & 17 & $65 \%$
\end{tabular}

Berdasarkan tabel tersebut, Soal dengan jumlah jawaban benar lebih dari atau sama dengan $50 \%$ dari total soal adalah nomor 2, 3, 5, 7, 8, 9, dan 10. Jika ditinjau lebih lanjut dari jenis kelamin, tidak ada perbedaan nilai yang siknifikan antara nilai laki-laki dan perempuan, kecuali pada nomor 3 sekitar 34\%. Penguasaan Konsep
Geometri Pada Siswa Masing-Masing SMP Sasaran.Pada penelitian ini, terdapat tujuh SMP/Sederajat yang menjadi targetan penelitian ini dengan total responden sebanyak 243 siswa. Berdasarkan nilai test kognitif yang didapatkan para siswa dari masing-masing sekolah, dapat dirangkum pada table di bawah ini.

Tabel 9. Rata-Rata Perolehan Nilai Siswa Tiap Sekolah Nama Sekolah

\section{Rata-Rata Nilai Total}

\begin{tabular}{cc}
\hline MTs. Al-Irsyad & 53 \\
MTs. Al-Ihsan & 54 \\
\hline SMPN 17 & 45 \\
\hline SMPN 18 & 68 \\
\hline SMPN 19 & 56 \\
\hline SMPN 20 & 60 \\
\hline SMPN 22. & 49 \\
\hline Rata-rata & $\mathbf{5 5}$
\end{tabular}

Terlihat perolehan nilai tersebut tergolong cukup rendah, karena terdapat beberapa siswa yang kurang menguasai konsep geometri dan ada konsep matematika lainnya yang berhubungan dengan penyelesaian soal tes, terutama seperti konsep perpangkatan dan bentuk akar yang pada soal tes terdapat pada soal nomor 1, hal ini diperkuat juga oleh pernyataan para siswa itu sendiri ketika ditanya materi apa saja yang sukar bagi mereka, hasilnya memang terdapat banyak siswa yang mengaku bahwa materi geometri khususnya materi Teorema Phytagoras dan materi matematika lainnya seperti bentuk akar memang merupakan materi yang sukar. Hal ini juga diperkuat oleh data soal dengan jumlah jawaban benar lebih dari atau sama dengan 50\% dari total soal untuk tiap sekolah yaitu: MTs. Al-Irsyad : 2,
3, 4, 5, 7, 8, 9 dan 10; MTs. Al Ihsan : 2, 4, 5, 8, 9 dan 10; SMP Negeri $17 \quad: \quad 2,4$, dan 8; SMP Negeri $18: 2,3,5,7,8$, 9, dan 10; SMP Negeri $19: 2,3,4,5,8$, dan 10; SMP Negeri 20 : $2,3,4,5,7,8,9$, dan 10; SMP Negeri $22: 2,3,5$, $7,8,9$, dan 10

Terlihat nomor 1 dan 6 tidak menjadi soal dengan jumlah jawaban benar lebih dari atau sama dengan $50 \%$ dari total soal. Untuk penjabaran masing-masing materi geometri akan dijelaskan pada sub pembahasan ketiga dari penelitian ini. Penguasaan Konsep Geometri Pada Siswa Masing-Masing SMP/Sederajat Dikaji Dari Jenis Kelamin.Berdasarkan rata-rata hasil tes yang sudah diklasifikasikan berdasarkan gender, seperti di bawah ini:

Tabel 10. Rata-Rata Perolehan Nilai Siswa Tiap Sekolah Berdasarkan Gender

\begin{tabular}{ccc}
\hline Nama Sekolah & Rata-rata Nilai Laki-Laki & Rata-rata Nilai Perempuan \\
\hline MTs. Al-Irsyad & 45 & 58 \\
\hline MTs. Al-Ihsan & 50 & 58 \\
\hline SMPN 17 & 58 & 31 \\
\hline SMPN 18 & 69 & 67 \\
\hline
\end{tabular}




\begin{tabular}{ccc}
\hline SMPN 19 & 60 & 51 \\
\hline SMPN 20 & 56 & 64 \\
\hline SMPN 22. & 41 & 56 \\
\hline Rata-rata & 54 & 55 \\
\hline
\end{tabular}

Terlihat bahwa tidak ada perbedaan yang signifikan, kecuali pada SMP Negeri 17 yang ratarata nilai laki-laki lebih tinggi daripada perempuan, hal ini terjadi karena terdapat perbedaan persentase jawaban benar pada nomor 2 sekitar $36 \%$, nomor 9 sekitar 48\%, dan nomor 10 sekitar $43 \%$. Namun, secara keseluruhan tidak ada perbedaan antara nilai tes geometri siswa lakilaki dan perempuan, karena nilai rata-rata laki-laki dan perempuan untuk seluruh sekolah adalah sekitar 54 dan 55.

\section{SIMPULAN DAN SARAN Simpulan}

Berdasarkan hasil penelitian dan pembahasan yang dipaparkan sebelumnya, dapat disimpulkan bahwa: (1) Penguasaan konsep geometri pada siswa masing-masing SMP/Sederajat Sasaran dengan perolehan nilai rata-rata dari seluruh sekolah adalah 55. Tergolong cukup rendah yang dikarenakan terdapat beberapa siswa yang kurang menguasai konsep geometri dan ada konsep matematika lainnya yang berhubungan dengan penyelesaian soal tes; (2) Tidak ada perbedaan yang signifikan terhadap penguasaan konsep geometri laki-laki ataupun perempuan masingmasing SMP/Sederajat Sasaran, kecuali pada salah satu sekolah yaitu SMP Negeri 17 yang dikarenakan laki-laki lebih unggul daripada perempuan di tiga soal dengan perbedaan persentase jumlah benar yang signifikan ; (3) Penguasaan konsep geometri masing-masing SMP Sasaran dikaji masing-masing materi geometri dinilai baik, kecuali pada soal nomor 1 dengan materi Teorema Phytagoras, karena dominan para siswa kurang dapat menggunakan hubungan antar konsep, terutama operasi bentuk perpangkaatan dan akar. Serta pada nomor 6 dengan materi perbandingan sisi pada bangun datar, karena dominan siswa cenderung lebih memilih mengamati gambar tanpa menghubungkannya dengan data yang disajikan pada soal.

Saran

Berdasarkan keterbatasan peneliti serta temuan yang ada pada saat penelitian, maka peneliti menyarankan beberapa hal sebagai berikut: (1) Peneliti selanjutnya diharapkan dapat membuat visualisasi soal yang lebih jelas; (2) Dalam pelaksanaan tes ini siswa dipersiapkan masih kurang matang, sebainya persiapan siswa dilakukan dengan matang sehingga pekerjaan mereka adalah hasil yang optimal.

\section{DAFTAR RUJUKAN}

Herman Hudojo. (2005). Pengembangan Kurikulum dan Pembelajaran Matematika. Malang: Universitas Negeri Malang

NCTM. (2000). Principles and Standards for School Mathematics. United States of America: The National Council of Teacher of Mathematics

Soedjadi, R. (2004). Pokok-Pokok Pikiran tentang Orientasi Masa Depan Matematika Sekolah di Indonesia. Media Pendidikan Matematika Nasional No.2 Tahun $1 \mathrm{hlm}$. 2842. Surabaya: PPs IKIP Surabaya.

Sugiyono. (2015). Metode Penelitian Kuantitatif Kualitatif dan $R \& D$. Bandung: Alfabeta.

Undang-Undang Republik Indonesia Nomor 20 Tahun 2003 Tentang Sistem Pendidikan Nasional 